\title{
STABILISASI TANAH EKSPANSIF MENGGUNAKAN KAPUR DAN SPENT CATALYST UNTUK TANAH DASAR PERKERASAN
}

\author{
Arifudin Nur \\ Magister Teknik dan \\ Sistem Transportasi \\ Universitas Gadjah Mada \\ Yogyakarta \\ arifudin_nur7@yahoo.com
}

\author{
Suryo Hapsoro Tri Utomo \\ Departemen Teknik Sipil dan \\ Lingkungan \\ Universitas Gadjah Mada \\ Yogyakarta \\ suryohapsoro@ugm.ac.id
}

\author{
M. Zudhy Irawan \\ Departemen Teknik Sipil dan \\ Lingkungan \\ Universitas Gadjah Mada \\ Yogyakarta \\ zudhyirawan@ugm.ac.id
}

\begin{abstract}
Expansive soils have high swelling and shrinkage potentials, which may cause damage to road structures. Therefore, stabilization is required. One method of stabilization is to use lime and spent catalysts with the aim of increasing carrying capacity and reducing swelling. Spent catalyst is a petroleum processing waste and classified as pozzolanic material. The addition of lime and spent catalysts can increase the CBR value and reduce swelling of soils. The results of this study indicate that the maximum increase in soaked CBR and unsoaked CBR values occurred in soil mixtures with optimum lime content and $12 \%$ spent catalyst with 7 days of curing. While the soil mixture with optimum lime content and $12 \%$ spent catalyst, with 7 days of curing, is the best mixture that produces soaked CBR value of $49.67 \%$, swelling of $0.15 \%$, and plasticity index value of $11.97 \%$, so the soil meets the requirements to be used as pavement subgrade.
\end{abstract}

Keywords: expansive soil, stabilization, road structure, subgrade, road pavement

\begin{abstract}
Abstrak
Tanah ekspansif memiliki potensi pengembangan dan penyusutan yang tinggi, sehingga dapat menyebabkan kerusakan struktur jalan. Oleh sebab itu, perlu dilakukan stabilisasi. Salah satu metode stabilisasi adalah menggunakan kapur dan spent catalyst dengan tujuan meningkatkan kapasitas dukung dan menurunkan swelling. Spent catalyst merupakan limbah pengolahan minyak bumi dan termasuk bahan pozzolan. Penambahan kapur dan spent catalyst mampu meningkatkan nilai CBR dan mereduksi swelling. Hasil studi ini menunjukkan bahwa peningkatan maksimum nilai CBR soaked maupun CBR unsoaked terjadi pada campuran tanah dengan kadar kapur optimum dan 12\% spent catalyst dengan peraman 7 hari. Sedangkan campuran tanah dengan kadar kapur optimum dan $12 \%$ spent catalyst, dengan peraman 7 hari, merupakan campuran terbaik yang menghasilkan nilai CBR soaked sebesar 49,67\%, swelling sebesar $0,15 \%$, dan nilai indeks plastisitas sebesar $11,97 \%$, sehingga tanah memenuhi syarat untuk digunakan sebagai tanah dasar perkerasan jalan.
\end{abstract}

Kata-kata kunci: tanah ekspansif, stabilisasi, struktur jalan, tanah dasar, perkerasan jalan

\section{PENDAHULUAN}

Perkerasan jalan yang paling banyak dilaksanakan di Indonesia adalah perkerasan lentur. Perkerasan ini, secara umum memiliki 3 lapisan, yaitu lapisan permukaan, lapisan pondasi, dan lapisan pondasi bawah, yang dihampar di atas tanah dasar. Tanah dasar, sebagai lapisan yang paling bawah, berfungsi sebagai tempat untuk meletakkan lapis perkerasan serta mendukung konstruksi perkerasan jalan di atasnya. 
Tanah dasar harus memiliki kekuatan atau daya dukung tanah yang cukup karena integritas struktur perkerasan bergantung pada stabilitas struktur tanah dasar. Apabila tanah yang akan digunakan untuk suatu proyek pembangunan memiliki sifat sangat lepas, sangat mudah tertekan, memiliki indeks konsistensi yang tidak sesuai, permeabilitas yang terlalu tinggi, atau sifat lain yang tidak diinginkan, tanah tersebut harus distabilisasi (Bowles dan Hainim, 1993).

Tanah ekspansif bersifat mudah mengalami kembang susut dan memiliki kapasitas dukung yang dinyatakan oleh nilai CBR, yang relatif rendah, memerlukan stabilisasi untuk memperbaiki karakteristik tanah tersebut. Stabilisasi secara kimiawi menggunakan kapur dirasa lebih cocok untuk tanah ekspansif yang merupakan golongan tanah berbutir halus. Selain itu, kapur mudah didapat dan harganya relatif murah.

Stabilisasi tanah ekspansif dengan menggunakan kapur dan spent catalyst diharapkan dapat memperbaiki sifat-sifat teknis tanah, seperti kekuatan, tekstur, kemudahan dikerjakan, dan plastisitas. Perbaikan sifat teknis tersebut diharapkan dapat menambah kapasitas dukung tanah, yang dinyatakan dengan CBR, sehingga tanah dapat digunakan sebagai tanah dasar perkerasan.

Tanah ekspansif merupakan istilah yang digunakan pada tanah yang mempunyai potensi pengembangan atau penyusutan yang tinggi oleh adanya pengaruh perubahan kadar air. Jenis tanah yang mudah berubah volumenya ini adalah tanah yang banyak mengandung lempung, terutama yang mengandung mineral montmorillonite (Hardiyatmo, 2014). Suatu tanah lempung dapat diperkirakan ekspansif apabila memiliki indeks plastisitas (PI) $\geq 20 \%$ (Bowles dan Hainim, 1993). Chen (1975) berpendapat bila tanah mempunyai PI > 35\% maka termasuk tingkat ekpansif sangat tinggi. Menurut Wesley (2017) jenis mineral lempung yang paling sering terdapat di lapangan adalah kaolinite, illite, dan momorillonite dengan besaran butiran lebih kecil dari 0,002 $\mathrm{mm}$. Mineral lempung inilah yang menghasilkan sifat lempung yang khusus, yaitu kohesi dan plastisitas.

Menurut Spesifikasi Umum 2010 Direktorat Jenderal Bina Marga (2014), Revisi 3, nilai CBR minimal tanah dasar yang disyaratkan, jika diuji sesuai SNI 03-1744-1989, adalah $6 \%$. Perubahan partikel tanah menjadi partikel yang lebih besar akibat proses kimia dalam suatu rentan waktu tertentu, akan memberikan kontribusi terhadap pembentukan susunan partikel yang lebih kompak dan saling kunci antarpartikel yang lebih baik, sehingga memberikan dampak terhadap daya dukung tanah yang cenderung semakin bertambah dan pengembangan (swelling) tanah menjadi berkurang.

Pada saat tanah dicampur dengan kapur dan ditambah air, dalam tanah berbutir halus timbul pertukaran kation dengan cepat dan terjadi reaksi penggumpalan yang menghasilkan perubahan struktur, dan membentuk partikel-partikel tanah dengan ukuran yang lebih besar. Pertukaran kation dan flokulasi menyebabkan perbaikan dengan cepat terhadap plastisitas tanah, kemudahan dikerjakan (workability), kekuatan, dan sifat-sifat tegangan-deformasinya (Hardiyatmo, 2013). Reaksi pozzolan dan kapur padam menghasilkan kristal $\mathrm{Ca}\left(\mathrm{SiO}_{3}\right)$ yang bersifat mengikat butiran lempung dengan butiran lempung serta butiran lempung dengan $\mathrm{Ca}\left(\mathrm{SiO}_{3}\right)$. Proses pozzolanisasi ini memerlukan waktu yang lama 
untuk mencapai kekuatan penuh, dengan reaksi pozzolanisasi yang terjadi adalah sebagai berikut:

$$
\mathrm{SiO}_{2}+\mathrm{Ca}(\mathrm{OH})_{2}+\mathrm{H}_{2} \mathrm{O} \rightarrow \mathrm{Ca}\left(\mathrm{SiO}_{3}\right)+2 \mathrm{H}_{2} \mathrm{O}
$$

Unsur $\mathrm{Ca}\left(\mathrm{SiO}_{3}\right)$ hasil pozzolanisasi berbentuk gel calcium silicate hydrates $(\mathrm{CSH})$, yang bersifat sebagai perekat antarpartikel tanah, sehingga menjadi satu kesatuan yang dapat meningkatkan kapasitas dukung tanah (Wiqoyah, 2002).

Dalam pengukuran nilai CBR terdapat 2 ketentuan yang menjadi dasar pembacaan, yaitu nilai CBR pada penetrasi 0,1 inci terhadap tekanan penetrasi standar sebesar 1.000 psi dan nilai CBR pada penetrasi 0,2 inci terhadap tekanan penetrasi standar sebesar 1.500 psi. Nilai CBR yang biasanya digunakan dalam perancangan adalah nilai CBR pada penetrasi 0,1 inci karena umumnya memiliki nilai lebih besar dari pada nilai CBR pada penetrasi 0,2 inci. Jika nilai CBR pada penetrasi 0,2 inci lebih besar daripada nilai CBR pada penetrasi 0,1 inci, pengujian sebaiknya diulang. Bila pada penetrasi 0,2 inci tersebut diperoleh nilai CBR tetap lebih besar, nilai CBR yang lebih besar tersebut yang digunakan dalam perancangan (Hardiyatmo, 2015).

\section{METODOLOGI PENELITIAN}

Penelitian ini dilaksanakan dengan melakukan pengujian di laboratorium. Bahan penelitian yang digunakan terdiri atas:

1) Bahan tanah yang berasal dari daerah Kecamatan Sentolo, Kabupaten Kulon Progo.

2) Bahan kapur didapat dari daerah Yogyakarta dengan spesifikasi kapur padam $\left(\mathrm{Ca}\left(\mathrm{OH}_{2}\right)\right.$, Calcium Hydroxyd), yang memiliki kandungan minimal 95\%.

3) Bahan spent catalyst yang diperoleh dari PT Pertamina-Refinery Unit IV Cilacap.

Penelitian dilakukan di Laboratorium Mekanika Tanah, Fakultas Teknik, Universitas Gadjah Mada, Yogyakarta. Sementara itu, penelitian komposisi mineral tanah (difraksi sinar-X) dilakukan di Laboratorium Pusat Geologi, Fakultas Teknik, Universitas Gadjah Mada Yogyakarta.

Variasi campuran stabilisasi tanah ekspansif dengan kapur menggunakan kadar kapur $0 \%, 2 \%, 4 \%, 6 \%$, dan $8 \%$ terhadap berat kering tanah. Hal ini mengacu pada Ingles dan Metcalf (1972), yang menyatakan bahwa penggunaan kapur padam (hidrated lime) yang disarankan untuk stabilisasi tanah lempung berkisar antara 3\%-8\% terhadap berat kering tanah.

Dari pencampuran tersebut didapat kadar kapur optimum berdasarkan nilai CBR. Kadar kapur optimum yang sudah didapat selanjutnya digunakan sebagai dasar pencampuran tanah ekspansif, dengan menggunakan kadar kapur optimum dan variasi kadar spent catalyst. Kadar spent catalyst ditentukan secara bebas, yaitu 0\%, 3\%, 6\%, 9\%, dan $12 \%$ terhadap berat kering tanah. 
Peraman dilakukan setelah pencampuran dan kemudian dipadatkan dalam cetakan, sesuai prosedur pelaksanaan pengujian berdasarkan ASTM D 698-00a. Permukaan bagian atas dan bagian bawah ditutup dengan plastik secara rapat, dan selanjutnya dibungkus kembali dengan kantong pastik yang diikat. Tujuan perlakuan tersebut adalah untuk mempertahankan kadar air benda uji selama masa peraman. Peraman dilakukan selama 7 hari untuk memberikan waktu bereaksi campuran secara kimiawi.

Pengujian pendahuluan dilakukan untuk mengetahui properties tanah yang digunakan. Uji pendahuluan tersebut meliputi uji mineralogi, uji specific gravity, uji batasbatas Atterberg, uji distribusi ukuran butiran, uji pemadatan, uji CBR soaked, uji CBR unsoaked, dan uji swelling. Dari uji pendahuluan ini didapat karakteristik awal tanah yang akan distabilisasi.

Pengujian campuran tanah dan kapur meliputi uji kepadatan, dengan tujuan mendapatkan kadar air optimum yang akan digunakan sebagai acuan pencampuran pada uji CBR. Variasi kadar kapur adalah 0\%, 2\%, 4\%, 6\%, dan $8 \%$ terhadap berat kering tanah. Uji CBR dimaksudkan untuk mencari nilai maksimum, sehingga didapat kadar kapur optimum, yang selanjutnya digunakan sebagai acuan campuran tanah dengan kapur dan spent catalyst.

Setelah mendapatkan kadar kapur optimum, dilanjutkan dengan penambahan kadar spent catalyst pada campuran dengan kadar bervariasi, yaitu 0\%, 3\%, 6\%, 9\%, dan 12\%. Pengujian yang dilakukan meliputi uji batas-batas Atterberg (ASTM D 4318-00 \& ASTM D 427-98), uji specific gravity (ASTM D 854-02), uji distribusi ukuran butiran (ASTM D 1140-00 dan ASTM D 422-63), uji pemadatan (ASTM D 698-00a), uji CBR soaked, uji CBR unsoaked (ASTM D 1883-99), dan uji swelling.

\section{HASIL DAN PEMBAHASAN}

\section{Tanah Asli}

Hasil uji tanah asli dapat dilihat pada Tabel 1 dan Tabel 2. Tanah yang digunakan sebagai sampel berasal dari Kecamatan Sentolo, Kabupaten Kulon Progo, dengan batas konsistensi LL sebesar 75,30\%, PL sebesar 29,91\%, SL sebesar 14,35\%, dan indeks plastisitas (PI) sebesar 45,39\% (lebih besar daripada 35\%), yang dikategorikan sebagai tanah dengan tingkat ekspansif sangat tinggi. Kandungan mineral yang paling dominan pada sampel tanah tersebut adalah smectite, yaitu sebesar 36,42\%. Mineral ini sering juga disebut sebagai montmorillonite, yang mempunyai gaya tarik yang kuat terhadap air, sehingga sangat mudah mengembang bila ada tambahan kadar air.

Menurut klasifikasi sistem AASHTO, tanah asli hasil pengujian diklasifikasikan golongan tanah A-7-6 dengan nilai GI sebesar 44,92 atau A-7-6(45), sehingga termasuk tipe material tanah berlempung dengan penilaian umum sebagai tanah dasar yang sangat buruk. Berdasarkan klasifikasi tersebut serta ditinjau dari nilai CBR terendam (soaked) sebesar 2,01\% (syarat subgrade minimal 6\%) dan nilai potensi pengembangan (swelling) 
sebesar 3,99\%, tanah tersebut memerlukan perbaikan karakteristik untuk dapat digunakan sebagai tanah dasar.

Tabel 1 Hasil Pengujian Karakteristik Tanah Asli

\begin{tabular}{clcr}
\hline No. & \multicolumn{1}{c}{ Karakteristik } & Satuan & Nilai \\
\hline 1 & Specific gravity (Gs) & & 2,644 \\
2 & Batas cair (LL) & $\%$ & 75,30 \\
3 & Batas plastis (PL) & $\%$ & 29,91 \\
4 & Indeks plastisitas (PI) & $\%$ & 45,39 \\
5 & Batas susut (SL) & $\%$ & 14,35 \\
6 & $\gamma k_{\text {maks }}$ & $\mathrm{gr} / \mathrm{cm}^{3}$ & 1,26 \\
7 & Kadar air optimum & $\%$ & 34,30 \\
8 & CBR unsoaked & $\%$ & 9,82 \\
9 & CBR soaked & $\%$ & 2,01 \\
10 & Swelling & $\%$ & 3,99 \\
11 & Fraksi kasar & $\%$ & 13,19 \\
12 & Fraksi halus & $\%$ & 86,81 \\
\hline
\end{tabular}

\section{Campuran Tanah dengan Kapur}

Hasil uji nilai CBR unsoaked tanpa peraman terhadap campuran tanah dengan variasi kadar kapur terlihat pada Gambar 1. Terdapat kecenderungan peningkatan nilai CBR seiring dengan bertambahnya kadar kapur sampai dengan kadar 6\%, yang disebabkan oleh proses flokulasi-aglomerasi reaksi kapur dengan tanah dan air sehingga butiran menjadi lebih besar dan beragam. Selain itu, proses sementasi mejadikan ikatan lebih kuat. Pencampuran tanah dan kapur dapat dengan segera meningkatkan kekuatan tanah sesudah pencampuran karena adanya reaksi cepat pertukaran kation, pengumpulan, dan penggumpalan. Sedangkan pada penambahan $8 \%$ kapur dihasilkan nilai CBR lebih rendah daripada penambahan $6 \%$ kapur, yang disebabkan jumlah kapur yang ditambahkan melebihi kebutuhan optimum untuk mengikat partikel butiran tanah. Dengan demikian kadar kapur optimum untuk campuran tanah adalah adalah $6 \%$.

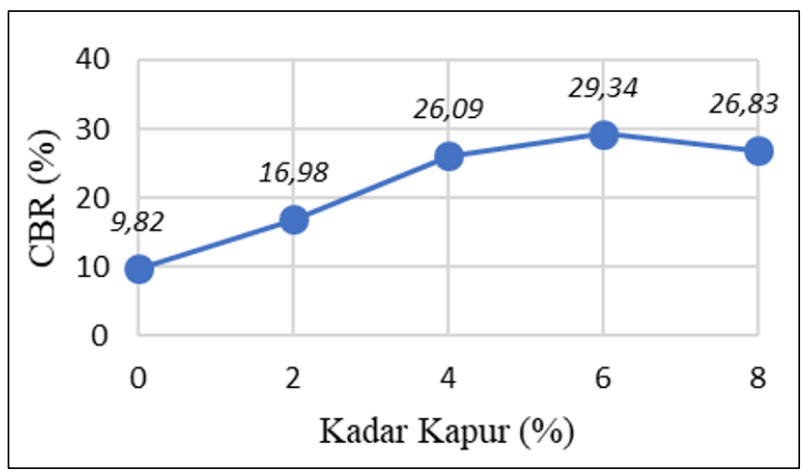

Gambar 1 Pengaruh Kapur terhadap Nilai CBR

Gambar 2 menunjukkan bahwa penambahan kapur optimum dan spent catalyst terhadap tanah asli menyebabkan penurunan nilai batas cair atau LL. Fenomena perubahan ini seiring dengan bertambahnya kadar spent catalyst. Hal tersebut disebabkan oleh adanya ion-ion kalsium (ion $\mathrm{Ca}^{2+}$ ) yang berlimpah pada bahan tambah menarik anion partikel 
tanah. Ion-ion $\mathrm{Ca}$ cenderung menggantikan kation-kation pada partikel lempung, dan proses ini menyebabkan partikel tanah menjadi pulverized. Nilai batas plastis atau PL tanah asli masih meningkat namun cenderung menurun seiring dengan peningkatan kadar spent catalyst. Sedikit penurunan tersebut akibat adanya mineral yang terkandung dalam spent catalyst mengurangi kebutuhan air untuk mempertahankan plastisitasnya. Perubahan nilai batas cair dan batas plastis tersebut menurunkan nilai indeks plastisitas atau PI campuran seiring dengan peningkatan kadar spent catalyst.

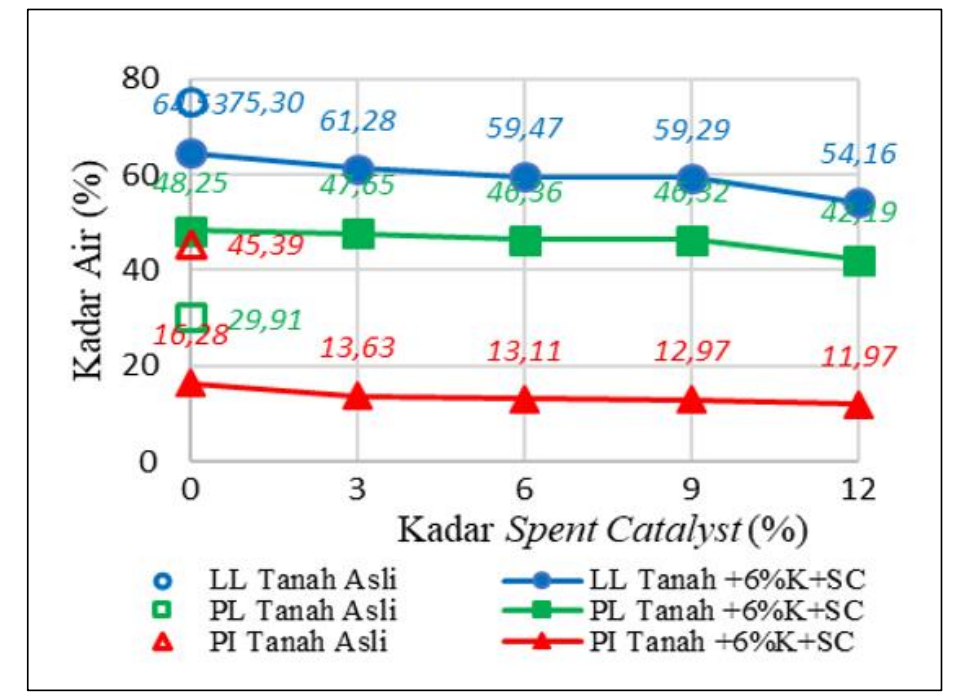

Gambar 2 Hubungan Variasi Campuran dengan Batas Konsistensi

Tabel 3 menunjukkan bahwa penambahan kapur dan spent catalyst mengakibatkan perubahan komposisi fraksi butiran, yaitu bertambahnya fraksi kasar seiring dengan bertambahnya spent catalyst. Kecenderungan ini dipengaruhi oleh proses kimiawi yang terjadi selama waktu peraman benda uji, yaitu terjadi perpindahan ion-ion $\mathrm{Ca}^{2+}$ dalam kapur dan spent catalyst yang diabsorpsi oleh partikel-partikel tanah, sehingga mengakibatkan menggumpalnya partikel dan menjadi partikel yang lebih besar. Selain itu, terbentuknya gel calcium silicate hydrates (CSH) mampu mengikat partikel-partikel tanah, sehingga menjadi partikel yang lebih besar dan kuat.

Tabel 3 Distribusi Ukuran Butiran Campuran

\begin{tabular}{lcccc}
\hline \multirow{2}{*}{$\begin{array}{c}\text { Variasi } \\
\text { Campuran }\end{array}$} & \multicolumn{4}{c}{ Distribusi Butiran (\%) } \\
\cline { 2 - 5 } & \multicolumn{2}{c}{ Tanpa Peraman } & Peraman 7 Hari \\
\cline { 2 - 5 } & FK & FH & FK & FH \\
\hline Tanah Asli & 13,19 & 86,81 & - & - \\
$\mathrm{T}+6 \% \mathrm{~K}$ & 17,75 & 82,25 & 6,74 & 73,26 \\
$\mathrm{~T}+6 \% \mathrm{~K}+3 \% \mathrm{SC}$ & 22,46 & 77,54 & 31,98 & 8,02 \\
$\mathrm{~T}+6 \% \mathrm{~K}+6 \% \mathrm{SC}$ & 23,69 & 76,31 & 45,51 & 54,49 \\
$\mathrm{~T}+6 \% \mathrm{~K}+9 \% \mathrm{SC}$ & 34,55 & 65,45 & 44,33 & 55,67 \\
$\mathrm{~T}+6 \% \mathrm{~K}+12 \% \mathrm{SC}$ & 37,94 & 62,06 & 47,82 & 52,18 \\
\hline $\mathrm{K}$
\end{tabular}

Keterangan: FK= Fraksi Kasar; $\mathrm{FH}=$ Fraksi Halus

$\mathrm{T}=$ Tanah; $\mathrm{K}=$ Kapur; $\mathrm{SC}=$ Spent Catalyst 
Proses hidrasi dan sementasi membutuhkan waktu. Seiring dengan pertambahan waktu, ikatan partikel-partikel menjadi semakin kuat. Peristiwa ini dibuktikan dengan kecenderungan jumlah fraksi kasar dan distribusi butiran pada peraman 7 hari lebih besar dibandingkan dengan tanpa peraman.

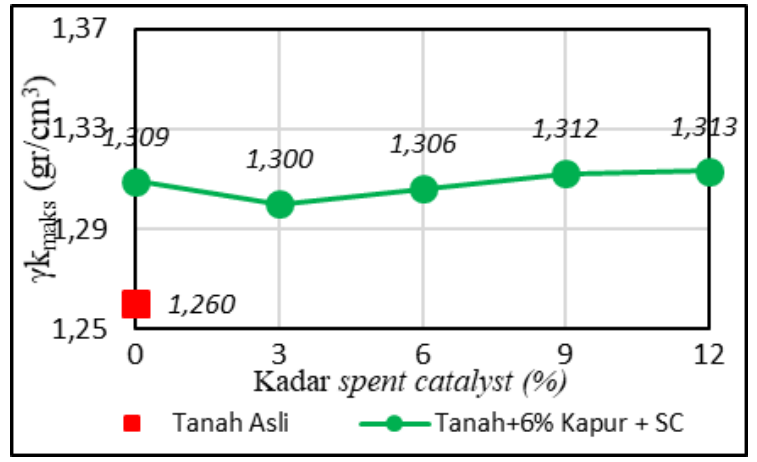

Gambar 3 Hubungan Variasi Campuran dengan $\gamma \mathrm{k}_{\text {maks }}$

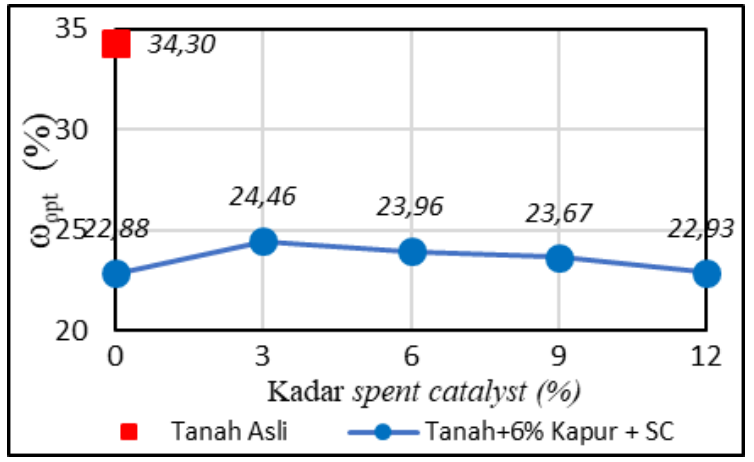

Gambar 4 Hubungan Variasi Campuran dengan $\omega_{\mathrm{opt}}$

Pada Gambar 3 dan Gambar 4 terlihat bahwa tejadi penurunan kadar air optimum $\left(\omega_{\text {opt }}\right)$ dan peningkatan berat volume kering maksimum ( $\left.\gamma \mathrm{k}_{\text {maks }}\right)$ seiring dengan meningkatnya kadar spent catalyst pada campuran. Hal tersebut terjadi karena adanya perubahan gradasi ukuran partikel tanah, yang menjadi lebih besar akibat penambahan kapur optimum dan seiring penambahan spent catalyst, sesuai dengan hasil pengujian distribusi ukuran butiran tanah pada campuran tersebut. Semakin besar partikel tanah, semakin menurun kohesi partikelnya, sehingga saat diberikan energi pemadatan akan menyebabkan sebagian terurai menjadi butiran yang lebih kecil dan membuat ukuran butiran menjadi lebih beragam. Gradasi yang lebih beragam akan membuat partikel tanah menjadi lebih rapat, sehingga membuat berat volume kering maksimum bertambah. Seiring dengan peristiwa tersebut akan terjadi penurunan kadar air optimumnya.

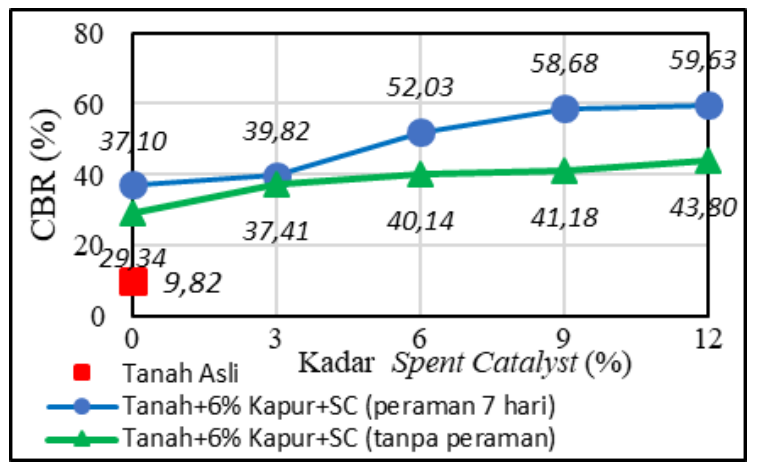

Gambar 5 Hubungan Variasi Campuran dengan CBR Unsoaked

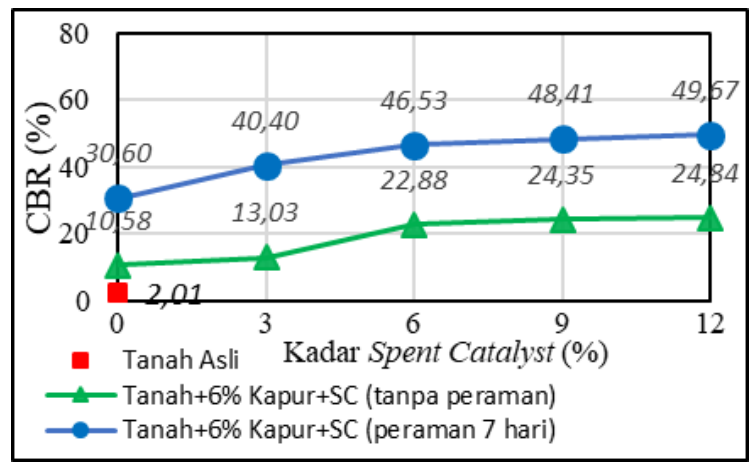

Gambar 6 Hubungan Variasi Campuran dengan CBR Soaked

Berdasarkan hasil pengujian CBR unsoaked maupun CBR soaked, Gambar 5 dan Gambar 6 menunjukkan bahwa nilai CBR mengalami peningkatan seiring dengan penambahan spent catalyst. Proses kimiawi yang terjadi antara partikel tanah dengan kapur dan 
spent catalyst mengubah ukuran butiran partikel tanah menjadi lebih besar. Susunan partikel yang lebih kompak dan saling kunci antarpartikel yang lebih baik dapat meningkatkan daya dukung tanah. Perubahan partikel menjadi lebih besar ditunjukkan oleh hasil pengujian distribusi ukuran butiran tanah. Dengan meningkatnya kadar spent catalyst, semakin bertambah jumlah fraksi butiran tertahan saringan No. 200. Reaksi antara pozzolan dan kapur serta air membentuk gel calcium-silicate-hydrate (CSH). Reaksi ini membentuk struktur yang lebih kokoh dengan ikatan yang kuat, sehingga mampu meningkatkan kapasitas dukung tanah.

Nilai CBR campuran dengan peraman selama 7 hari lebih besar dibandingkan dengan Nilai CBR campuran tanpa peraman. Peningkatan nilai CBR ini dikarenakan adanya waktu yang lebih lama untuk terjadinya reaksi kapur dan spent catalyst dengan partikel tanah. Seiring dengan lamanya waktu, membuat proses terjadinya flokulasiaglomerasi semakin berdampak pada pembesaran partikel tanah. Dengan membesar dan beragamnya ukuran butiran partikel tanah, secara otomatis memperbesar bidang gesek dan sudut gesek dalam, sehingga kapasitas dukung tanah meningkat. Nilai CBR tertinggi terdapat pada variasi campuran tanah dengan $6 \%$ kapur dan $12 \%$ spent catalyst, dengan peraman selama 7 hari, yaitu sebesar $59,63 \%$, atau terjadi peningkatan sebesar 506,93\% terhadap nilai CBR tanah asli, yaitu $9,82 \%$.

Nilai swelling campuran tanpa peraman lebih besar daripada nilai swelling tanah asli. Seperti ditunjukkan pada Gambar 7, hal ini disebabkan karena belum cukup waktu untuk terjadinya reaksi kimia antarbahan campuran dengan tanah. Karena itu, $\mathrm{Ca}^{2+}$ dalam campuran yang belum bereaksi dengan permukaan negatif partikel tanah, berikatan kembali dengan hidroksida dan membentuk hydrated lime, yang bersifat higroskopis dan menyerap air.

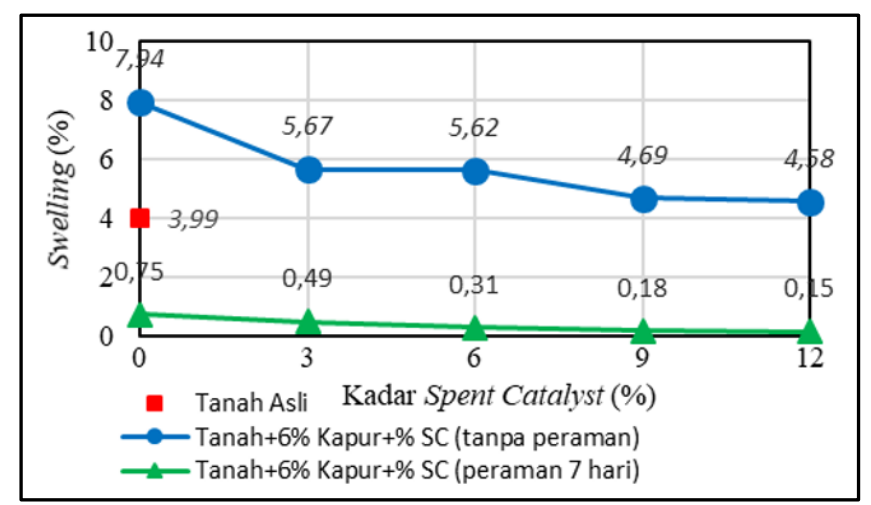

Gambar 7 Hubungan Variasi Campuran dengan Swelling

Pada perlakuan campuran peraman 7 hari sebelum direndam, terjadi penurunan nilai swelling akibat penambahan kapur optimum dan spent catalyst. Penurunan nilai swelling ini terjadi seiring dengan bertambahnya spent catalyst pada campuran. Peristiwa ini disebabkan karena reaksi kimia sudah berjalan baik seiring dengan bertambahnya waktu. Semakin membesarnya partikel akan mengecil luas permukaan spesifik (specific 
surface) dan membentuk gel calcium-silicate-hydrate (CSH) yang memberi ikatan yang kuat antarpartikel dan sulit ditembus oleh air.

\section{KESIMPULAN}

Dari penelitian ini dapat ditarik beberapa kesimpulan sebagai berikut:

1) Penambahan spent catalyst dan kapur pada tanah yang dikaji pada penelitian ini menyebabkan adanya tarik menarik antara ion $\mathrm{Ca}^{2+}$ dengan anion partikel tanah dan pertukaran kation (cation exchange). Hal ini menjadikan partikel tanah pulverized, sehingga menurunkan kohesi partikel, yang berpengaruh terhadap nilai batas konsistensi. Peristiwa flokulasi-aglomerasi yang menyertai proses pertukaran ion-ion menghasilkan ukuran butiran yang lebih besar dan beragam, sehingga meningkatkan jumlah fraksi kasar, dan terbentuknya gel calcium-silicate-hydrate (CSH) yang mampu lebih meningkatkan nilai CBR dan menurunkan nilai swelling. Perbaikan karakteristik tanah semakin meningkat seiring dengan penambahan waktu.

2) Penambahan kapur dan spent catalyst mampu meningkatkan nilai CBR dan mereduksi swelling. Peningkatan nilai CBR soaked maupun CBR unsoaked maksimum terjadi pada campuran tanah dengan kadar kapur optimum dan $12 \%$ spent catalyst dengan peraman 7 hari.

3) Campuran tanah dengan kadar kapur optimum dan $12 \%$ spent catalyst, dengan peraman 7 hari, merupakan campuran terbaik yang menghasilkan nilai CBR soaked sebesar 49,67\%, swelling sebesar 0,15\%, dan nilai indeks plastisitas sebesar 11,97\%, yang memenuhi syarat sebagai tanah dasar perkerasan jalan.

\section{DAFTAR PUSTAKA}

American Society for Testing and Materials (ASTM) C618-92a. 2005. Standard Specification for Fly Ash or Raw or Natural Pozzolan for Use as a Mineral Admixture in Portland Cement Concrete: Annual Book of ASTM Standards. West Conshohocken, PA.

Bowles, J.E dan Hainim, J.K. 1993. Sifat-Sifat Fisis dan Geoteknis Tanah (Mekanika Tanah). Edisi Kedua. Jakarta: Penerbit Erlangga.

Chen, F.H. 1975. Foundation of Expansive Soils. New York, NY: Elsevier Scientific Publishing.

Direktorat Jenderal Bina Marga. 2014. Spesifikasi Umum 2010. Revisi 3. Kementerian Pekerjaan Umum dan Perumahan Rakyat. Jakarta.

Hardiyatmo, H.C. 2013. Stabilisasi Tanah untuk Perkerasan Jalan. Cetakan Kedua. Yogyakarta: Gadjah Mada University Press. 
Hardiyatmo, H.C. 2014. Tanah Ekspansif: Permasalahan dan Penanganan. Edisi Pertama Cetakan Pertama. Yogyakarta: Gadjah Mada University Press.

Hardiyatmo, H.C. 2015. Perancangan Perkerasan Jalan dam Penyelidikan Tanah. Edisi Kedua. Yogyakarta: Gadjah Mada University Press.

Ingles, O.G. dan Metcalf, J.B. 1972. Soil Stabilization-Principles and Practice. Sydney: Butterworths.

Wesley, L.D. 2017. Mekanika Tanah. Edisi Kedua. Terjemahan. Yogyakarta: Andi.

Wiqoyah, Q. 2002. Campuran Kapur dan Tras sebagai Bagian Stabilisasi Tanah Lempung Hitam untuk Lapisan Tanah Dasar Jalan. Tesis tidak diterbitkan. Yogyakarta: Magister Teknik Sipil, Jurusan Ilmu-Ilmu Teknik, Fakultas Teknik, Universitas Gadjah Mada. 